\title{
ВІКОВІ ОСОБЛИВОСТІ ЗМІН ПОКАЗНИКІВ ЕНДОГЕННОЇ ІНТОКСИКАЦІЇ І СТАН МЕМБРАН ЗА ДІЇ ВАЖКИХ МЕТАЛІВ ТА ГЛІФОСАТУ
}

Вступ. Важкі метали - група ксенобіотиків, які мають найбільшу стійкість у навколишньому середовищі, та політропні токсини для людства. В основі дії важких металів лежить блокування функціонально активних груп структурних протеїнів, протеїнів-ензимів, найбільше значення має блокування сульфгідрильних (тіольних, SH) груп. За дії важких металів більшість протеїнів втрачає свої фрізико-хімічні та біологічні властивості, що призводить до порушення протеїнового й іншого обміну речовин.

Мета дослідження - вивчити вплив Плюмбуму ацетату, Купруму сульфрату і гліфосату (в фрормі гербіциду раундапу) та коригувальну дію цистеїл-гістидил-тирозил-гістидил-ізолейцину на зміни показників ендогенної інтоксикації і стан мембран у щурів різного віку.

Методи дослідження. Досліди проводили на лабораторних нелінійних білих щурах-самцях 3 вікових періодів (статевонезрілих, статевозрілих і старих), яким внутрішньошлунково впродовж 30 днів вводили водні розчини Плюмбуму ацетату, Купруму сульфату і гліфосату (в формі раундапу). 3 метою корекції на 21-й день через 6 год після введення токсикантів упродовж 10 днів вводили пептид (цистеїл-гістидил-тирозил-гістидил-ізолейцин). У сироватці крові уражених та коригованих щурів визначали активність аланінамінотрансфрерази (АлАТ, КФ 2.6.1.2), аспартатамінотрансфрерази (АсАТ, КФ 2.6.1.1) та вміст молекул середньої маси (МСM).

Результати й обговорення. Як показали наші дослідження, введення Плюмбуму ацетату, Купруму сульфрату і гліфосату призводило до зміни показників білкового обміну в тварин різного віку. Ці токсиканти збільшували вміст МСМ та активність амінотрансфераз у плазмі крові уражених щурів. За дії Плюмбуму ацетату, Купруму сульфрату і гліфросату та їх поєднання спостерігали підвищення активності амінотрансфрераз у сироватці крові тварин. Найбільш виражене зростання активності цих ензимів відзначали у щурів 3-місячного віку. Таким чином, активність ензиму АлАТ була вищою на 164 \% при ураженні Купруму сульфратом, на 184 \% - Плюмбуму ацетатом, на 276 \% - гліфосатом, на 428 \% - за їх комбінованого ураження порівняно з контролем (інтактні тварини). Активність ензиму АсАТ змінювалася так само, як і активність АлАТ. Вона зросла у 2,6; 2,7; 2,1 раза у сироватці крові 3-, 6- та 24-місячних тварин із комбінованим ураженням $(p<0,05)$ відповідно.

Висновки. За 30-денної токсичної дії Плюмбуму ацетату, Купруму сульфрату і глісросату (в фрормі раундапу) в дозі 1/20 LD 50 пригнічуються фрункції печінки. Підвищення вмісту МСм та активності амінотранссрераз (АлАТ, АсАT) у сироватці крові вказує на синдром токсичного гепатиту. Введення пептиду (цистеїл-гістидил-тирозил-гістидил-ізолейцину) як коригувального чинника щурам різного віку з токсичним ураженням печінки знижує ензимну активність амінотранссрераз та вміст молекул середньої маси.

КЛЮчОВІ СЛОВА: Плюмбуму ацетат; Купруму сульфрат; гліфосат; молекули середньої маси; амінотрансферази.

ВСТУП. За сучасними уявленнями [1, 2], перебіг та наслідки токсичних уражень печінки, як і багатьох інших захворювань внутрішніх органів, визначаються певною мірою розвитком ендогенної інтоксикації, яку можна охарактеризувати як неспецифічний за більшістю клінічних та біохімічних проявів синдром, що супроводжується невідповідністю між утворенням і виведен-

(с) Є. Б. Дмухальська, М. М. Корда, 2021. ням як продуктів нормального обміну, так і речовин спотвореного метаболізму [2-4].

За умов патології рідко створюється ситуація, коли ендогенна інтоксикація формується лише одним із вказаних шляхів. Частіше ії прояви та нагромадження ендогенних токсинів $€$ результатом поєднання різних за етіологією патогенних фракторів, взаємозумовлених наявністю численних нервових, гуморальних, ендокринних та 
креаторних зв'язків, які мають автокаталітичні властивості й каскадний характер розвитку [4].

Гостру ниркову та печінкову недостатність, опікову хворобу, інфрекційні хвороби, гострі захворювання черевної порожнини, а також токсикози, викликані дією ксенобіотиків, супроводжує ендогенна інтоксикація $[4,5]$, що спричиняє посилення процесів катаболізму 3 утворенням нових токсичних продуктів. За даними деяких авторів [5, 6], до таких речовин належать так звані молекули середньої маси (МСM). Їх розглядають як один із відповідних клінічних індикаторів, що визначають розвиток патологічного процесу [7, 8].

Молекулами середньої маси вважають гетерогенну групу речовин, до складу якої входять поліпептиди й ароматичні амінокислоти, які накопичуються при порушенні фрункціональної здатності систем детоксикації і посиленому катаболізмі протеїнів, нуклеопротеїнів, деяких гуморальних регуляторів (інсулін, глюкагон, спермін, вітаміни). Сюди належать і речовини вуглеводної природи, похідні глюкуронової кислоти і деяких спиртів, інші неідентиоріковані сполуки, які самі по собі можуть мати ушкоджувальний токсичний вплив на мембрани клітин, збільшувати проникність судин, викликати тканинну гіпоксію [8-10]. Хоча ці речовини є складовими компонентами відповідних біологічних рідин у нормі, проте при всіх патологічних станах констатовано, що їх співвідношення та концентрація змінюються, встановлено кореляційні зв'язки між цими змінами і тяжкістю перебігу токсичного процесу. Молекули середньої маси визначають темп розвитку синдрому ендогенної інтоксикації внаслідок їх впливу на основні гомеостатичні системи $[3,11,12]$.

Утворення надмірної кількості МСМ в організмі й розподіл їх у біологічних рідинах зумовлені порушенням рівноваги між процесами анаболізму і катаболізму в сторону останнього, що сприяє ураженню токсичними метаболітами відповідних органів та порушенню детоксикуючої функції печінки і видільної фрункції нирок. Молекули середньої маси - це речовини, що мають як різну масу, так і різні природу та фрункції. Зміни вмісту і складу фрракцій середніх молекул характерні для патогенезу ряду захворювань. Однак при оцінці змін концентрації МСМ необхідно надавати значення кількісним відхиленням не лише в сторону збільшення, але і в сторону їх зменшення, а також співвідношенням вимірюваних фрракцій $[10,12]$.

Токсична дія МСМ пов'язана насамперед із змінами проникності мембран, мембранного транспорту та роз'єднувальним впливом МСМ на процеси окисного фросфорилювання [5, 11].
Таким чином, збільшений вміст певних фрракцій МСM при ураженні вказує не лише на ступінь інтоксикації, але, мабуть, і на утворення захисних компонентів, які адаптують організм до складних умов.

Дестабілізація плазматичних мембран та мембран органел - одне з головних явищ, що лежать в основі цілого ряду патологічних процесів та пов'язані з підвищеним білковим катаболізмом або деструкцією тканин, ушкодженням видільних і детоксикаційних систем організму $[10,12]$.

При різних захворюваннях спостерігають ензимну дезорганізацію і зміну проникності (лабілізацію) мембран внутрішньоклітинних органел (лізосом, ендоплазматичного ретикулума, мітохондрій) печінки, нирок та інших органів і систем експериментальних тварин [11]. Першою ознакою порушення цілісності плазматичних мембран гепатоцитів при ряді захворювань (вірусних і токсичних гепатитах, цирозах печінки тощо) було підвищення у сироватці крові активності ензимів печінкового походження: аланінамінотрансферази (АлАТ, КФ 2.6.1.2), аспартатамінотрансферази (АсАТ, КФ 2.6.1.1), фрруктозо1,6-дифосфратальдолази, лактатдегідрогенази, оскільки при токсичному ураженні гепатоцитів вони першими виходять у судинне русло. Аланінамінотранссрераза локалізується в цитоплазмі, тому порушення проникності клітинних мембран призводить до зростання активності цього ензиму в сироватці крові. Доведено, що, чим вища активність АлАТ у плазмі крові, тим більші дистрофія і некроз гепатоцитів $[8,10]$. Практичне використання для характеристики цитолітичного процесу, крім активності АлАТ, отримало визначення АсАТ, яка локалізується в цитоплазмі й мітохондріях. Деякі автори [10] відмічають важливу діагностичну роль визначення активності АсАТ у сироватці крові при експериментальному токсичному гепатиті у кроликів, викликаному тетрахлорметаном. Вони пов'язують її збільшення при гепатитах із розпадом асоційованих фрорм ензиму на активніші продукти дисоціації. Печінка чутливіша до інтоксикації, ніж інші органи, і раніше реагує на неї. Згідно 3 даними літератури [12], підвищення у крові активності ензимів АлАТ і АсАТ при захворюваннях печінки тісно корелює зі ступенем деструкції гепатоцита.

Таким чином, ендогенна інтоксикація, яка $€$ важливим компонентом патогенезу захворювань, викликає деструкцію мембран усіх клітин та органел, сприяє підвищенню активності ензимів, порушує детоксикуючу функцію печінки. Збільшення показників ендотоксемії залежить від характеру патологічного процесу і може при- 
звести до наростання токсичного ефекту ксенобіотиків.

Для послаблення токсичної дії та виведення 3 організму важких металів застосовують комплексоутворювачі, які мають здатність утворювати з металами нетоксичні сполуки (хелати) і цим послаблювати їх токсичну дію в організмі [13]. Гепатозахисний ефект проявляють сполуки, які містять у своїй структурі сульсргідрильні групи (SH-групи). До сполук, які часто використовують з метою знешкодження гепатотропних ксенобіотиків, належать унітіол, цистеїн, ацетилцистеїн, цистамін тощо $[13,14]$.

У літературі існують дані про участь амінокислот та олігопептидів у вільнорадикальних процесах [15]. Активно включаються в ці процеси сірковмісні амінокислоти, ароматичні - триптофран, тирозин, френілаланін, гістидин, пролін. Гістидин є не тільки пасткою вільних радикалів, а й хелатором. У плазмі крові він утворює комплекс із міддю, який бере участь у дисмутації $\mathrm{O}_{2}^{-}$ $[13,15]$. Будучи фрізіологічно активними сполуками, пептиди проявляють модулюючу дію на функціональний стан усіх складових ланок гомеостазу людини і тварини. Тому з метою корекції порушень, викликаних Плюмбуму ацетатом, Купруму сульсратом та гліфосатом, ми використовували пептид цистеїл-гістидил-тирозилгістидил-ізолейцин.

Мета дослідження - вивчити вплив Плюмбуму ацетату, Купруму сульфату і гліфосату (в орормі гербіциду раундапу) та коригувальну дію цистеїл-гістидил-тирозил-гістидил-ізолейцину на зміни показників ендогенної інтоксикації і стан мембран у щурів різного віку.

МЕТОДИ ДОСЛІДЖЕННЯ. 3 метою вивчення впливу важких металів у поєднанні з фроссророрганічними пестицидами на окиснювальні процеси використовували лабораторних нелінійних білих щурів-самців 3 вікових періодів: статевонезрілих (молодих масою 70-90 г і віком 1-3 місяці), статевозрілих (дорослих масою 170-210 г та віком 5-8 місяців), старих (масою 250-300 г і віком 20-24 місяці). Вік тварин визначали за схемою В. І. Махінько та В. Н. Нікітіна [16].

Хімічний токсикоз у щурів викликали шляхом щоденного перорального введення їм упродовж 30 діб водних розчинів Плюмбуму ацетату $\left(\left(\mathrm{CH}_{3} \mathrm{COO}\right)_{2} \mathrm{~Pb}\right)$ в дозі 11 мг/кг маси тіла $\left(1 / 20 \mathrm{LD}_{50}\right)$, Купруму сульфрату (CuSO 4$)$ в дозі 13 мг/кг маси тіла (1/20 LD $\left.{ }_{50}\right)$, глісросату (у формі гербіциду раундапу) в дозі 250 мг/кг маси тіла (1/20 LD $\left.{ }_{50}\right)$. Токсиканти вводили у комбінації та окремо. Як контроль використовували інтактних тварин, яким вводили питну водопровідну дехлоровану воду. 3 метою корекції виявлених порушень на 21-й день експерименту через 6 год після введення токсикантів щодня протягом 10 днів вводили пептид цистеїл-гістидил-тирозил-гістидил-ізолейцин у дозі 9 мг/кг маси тіла (концентрації амінокислот у крові).

Піддослідних тварин усіх вікових періодів було поділено на такі групи: 1-ша-інтактні (контрольні); 2-га - уражені водним розчином Купруму сульфрату; 3-тя - уражені водним розчином Плюмбуму ацетату; 4-та - уражені водним розчином гліфосату (раундапу); 5-та - уражені водними розчинами Плюмбуму ацетату, Купруму сульфрату і раундапу; 6-та - з корекцією пептидом. На 31-шу добу після останнього введення ксенобіотиків і пептиду щурів виводили з експерименту за умов тіопентал-натрієвого (внутрішньочеревне введення $1 \%$ розчину з розрахунку 50 мг/кг маси тварини) наркозу.

Вплив токсикантів на зміни показників ендогенної інтоксикації і стан мембран в організмі уражених щурів оцінювали за активністю АлАТ, AсAT і вмістом МСM [6]. Активність амінотрансфераз у сироватці крові визначали уніфікованим динітрофенілгідразиновим методом Райтмана Френкеля, використовуючи стандартні набори фрірми “Філісіт-Діагностика" (Україна). Метод базується на визначенні щавлевооцтової і піровиноградної кислот (ПВК), які є субстратами реакцій переамінування з участю, відповідно, АсАТ та АлАТ. Субстрати з 2,4-дисенілгідразиновим реактивом утворюють забарвлений у відповідний колір продукт, інтенсивність якого пропорційна активності ензиму, і визначали її на біохімічному аналізаторі "Humalyzer 2000".

Під час проведення досліджень усі щури перебували у віварії Тернопільського національного медичного університету імені І. Я. Горбачевського МОЗ України на стандартному раціоні відповідно до санітарно-гігієнічних норм. Утримували щурів та виконували всі експерименти на них із дотриманням національних (Закон України № 3447-IV “Про захист тварин від жорстокого поводження", 2006) та міжнародних (Європейська конвенція про захист хребетних тварин, що використовуються для дослідних та інших наукових цілей, Страсбург, 1986) загальних правил і рекомендацій щодо гуманного поводження з лабораторними тваринами [1719].

Статистичну обробку цифрових даних здійснювали за допомогою програмного забезпечення Excel ("Microsoft", США) і STATISTICA 6.0 ("Statsoft", США) з використанням непараметричних методів оцінки одержаних даних. Для всіх показників розраховували значення середньої арифрметичної вибірки (М), її дисперсії і помилки 
середньої (m). Достовірність різниці значень між незалежними кількісними величинами встановлювали за допомогою критерію Манна - Уїтні. Зміни вважали статистично достовірними при $\mathrm{p}<0,05$ [20].

РЕЗУЛЬТАТИ Й ОБГОВОРЕННЯ. ЯК маркери ендогенного токсичного синдрому використовували молекули середньої маси. Оскільки синдром ендогенної інтоксикації супроводжується порушенням фрункціонального стану плазматичних і субклітинних мембран, ми вважали доцільним дослідити зміни активності амінотрансфрераз $[10,21]$.

Як показали наші дослідження (рис. 1), в інтактних тварин з віком у сироватці крові збільшувався вміст молекул середньої маси $\left(\mathrm{MCM}_{1}\right.$ $\mathrm{MCM}_{2}$ ), які відображають: $\mathrm{MCM}_{1}$ - вміст ланцюгових амінокислот, а MCM $_{2}$ - ароматичних амінокислот у середньомолекулярних пептидах та продуктах їх розпаду. Максимальні значення $\mathrm{MCM}_{1}$ і $\mathrm{MCM}_{2}$ відмічено у старих щурів $\left(\mathrm{MCM}_{1}-\right.$ $\left.0,383 \pm 0,011, \mathrm{MCM}_{2}-0,134 \pm 0,009\right)$. Це можна пояснити віковими особливостями метаболізму, що проявляються зниженням з віком активності гідролаз, які розщеплюють ушкоджені та модифріковані протеїни.

Введення Плюмбуму ацетату, Купруму сульфрату і гліфосату окремо та разом викликало порушення вмісту МСМ у сироватці крові щурів. Так, цей показник перебував на підвищеному рівні в усіх групах уражених тварин (див. рис. 1). При хімічному токсикозі, викликаному комбінованою дією водних розчинів Плюмбуму ацетату, Купруму сульфрату і глісросату, вміст $\mathrm{MCM}_{1}$ зріс у молодих тварин в 1,8 раза, а в дорослих і старих - в 1,6 раза порівняно з інтактними щурами $(\mathrm{p}<0,05)$. Аналогічних змін зазнав вміст $\mathrm{MCM}_{2}$, він становив 270, 173 та 266 \% від рівня контролю (інтактні тварини).

Ці дані вказують на те, що введення ксенобіотиків супроводжується посиленням катаболічних процесів та порушенням структури і фрункції клітинних мембран.
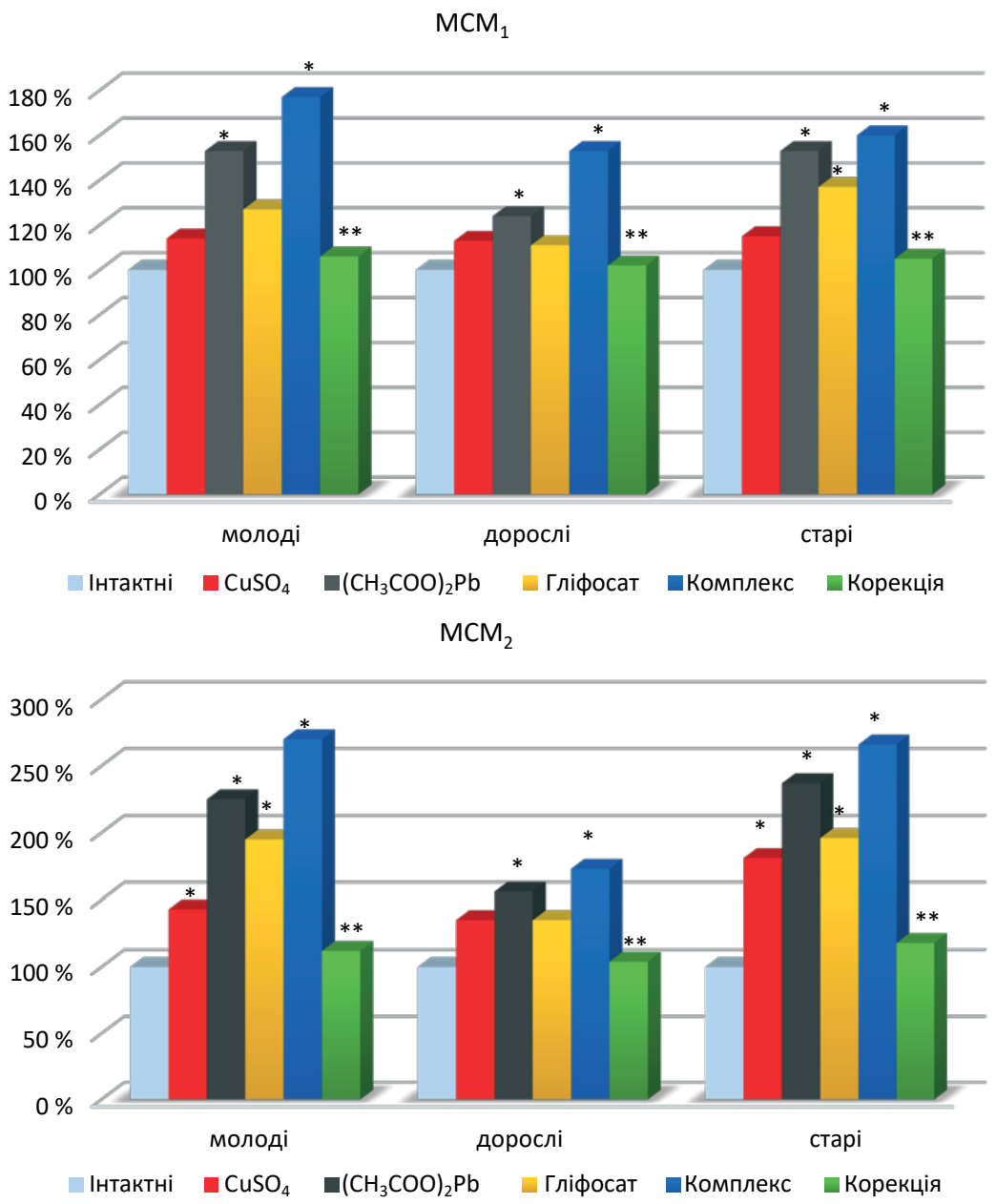

Рис. 1. Зміни ензимної активності обох складових молекул середньої маси (ум. од.) у крові щурів, уражених Плюмбуму ацетатом, Купруму сульсратом і глісоссатом ( $\mathrm{M} \pm \mathrm{m}, \mathrm{n}=10)$.

Примітка. Тут і на рисунку 2: * - результати достовірні відносно інтактних тварин $(p<0,05) ;$ ** - результати достовірні відносно показників у щурів при комбінованому ураженні $(p<0,05)$. 
Як відомо, вміст цитоплазматичних ензимів у плазмі крові та позаклітинному просторі тканин перебуває на відносно низькому рівні. Також відомо, що, незалежно від фрактора, який ініціює реакцію окиснення або переокиснення ліпідів, збільшується проникність мембран, що призводить до ряду змін усередині клітини (ушкодження клітинних органел) і виходу ензимів у позаклітинний простір [1, 11].

На підвищення проникності й ушкодження структури мембран при дії ксенобіотиків вказували зміни активності органоспецифічних ензимів. На рисунку 2 наведено зміни ензимної активності АлАТ, АсАТ за умов окремого та комбінованого впливу Плюмбуму ацетату, Купруму сульсрату і гліфосату в сироватці крові щурів різного віку.

У плазмі крові інтактних тварин найнижчою була активність АлАТ у молодих щурів $((3,59 \pm 0,29)$ кмоль ПВК/(г протеїнухгод)) порівняно $з$ дорослими $((4,80 \pm 0,41)$ кмоль ПВК/(г протеїнухгод)) і старими $((6,35 \pm 0,04)$ кмоль ПВК/ (г протеїнухгод)) тваринами, що, очевидно, по- в'язано з особливостями метаболізму амінокислот. Відмінною також була динаміка зміни активності АлАТ у крові уражених тварин. Найбільш виражене зростання активності цього ензиму відмічено у щурів 3-місячного віку. Так, ензимна активність АлАТ у крові за дії Купруму сульсрату становила 164 \%, Плюмбуму ацетату - $184 \%$, глісосату - $276 \%$, при їх комбінованій дії - 428 \% від рівня контролю (інтактні тварини).

Подібних змін зазнав ще один цитозольний ензим - АсАТ. Як видно з рисунка 2, в інтактних тварин його активність у плазмі крові була найвищою в старих щурів - $(6,75 \pm 0,31)$ кмоль ПВК/ (г протеїнухгод). У тварин усіх вікових періодів із токсикозом, викликаним введенням Плюмбуму ацетату, Купруму сульфрату і гліфросату окремо й одночасно, активність досліджуваного ензиму в плазмі крові зазнала однотипних, спрямованих у бік зростання, змін і при комбінованій дії токсикантів у сироватці крові молодих щурів становила 296 \% від рівня інтактних тварин, дорослих - $271 \%$, старих - $215 \%$ $(p<0,05)$.

АлАТ

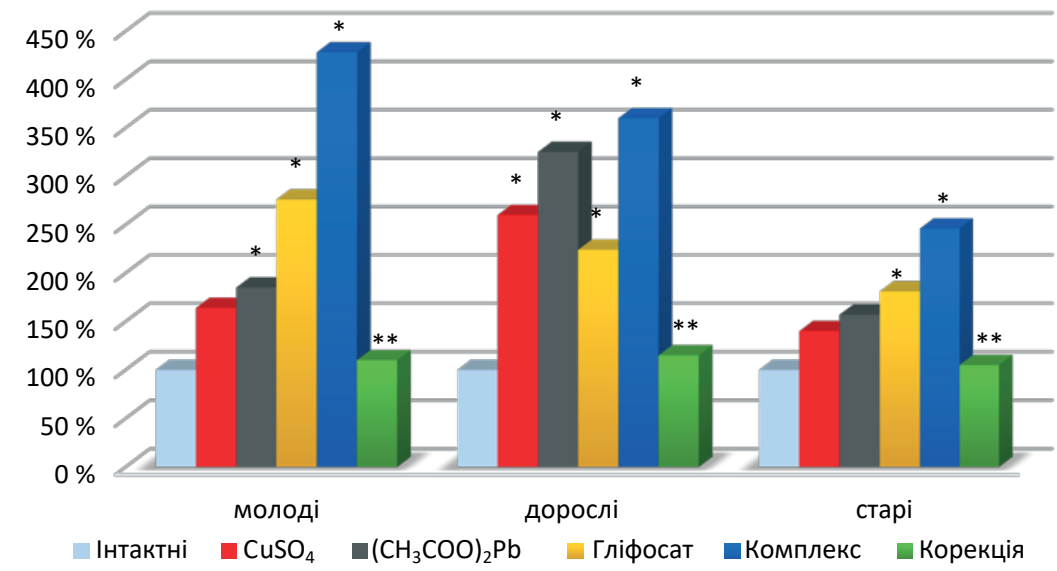

AcAT

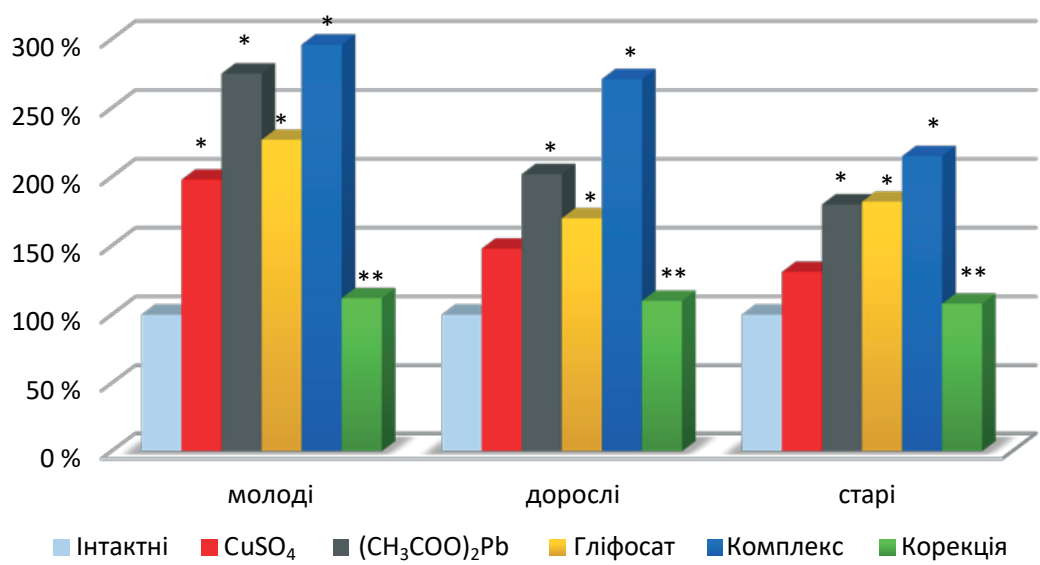

Рис. 2. Зміни ензимної активності аланін- та аспартатамінотранссрераз (кмоль ПВК/(г протеїнухгод)) у крові щурів, уражених Плюмбуму ацетатом, Купруму сульсратом і глісросатом (M $\pm m, n=10)$. 
Підвищення активності АсАТ у сироватці крові уражених тварин може бути зумовлене виходом у кров як цитозольної, так і мітохондріальної АсАТ, що спостерігають за умов ушкодження плазматичних і мітохондріальних мембран гепатоцитів та клітин інших органів і тканин, зокрема серця, скелетних м'язів, нирок тощо.

Такі дані вказують на те, що введення ксенобіотиків супроводжується посиленням катаболічних процесів, порушенням структури і фрункції клітинних мембран та розвитком токсичного синдрому. 3 метою корекції цих порушень ми використовували низькомолекулярний пептид-цистеїл-гістидил-тирозил-гістидил-ізолейцин. При його введенні активність ензиму знижувалася, проте рівня контролю не досягала.

ВИСНОВКИ. 1. Інтоксикація впродовж 30 днів Плюмбуму ацетатом, Купруму сульфатом і гліфосатом у формі раундапу в допорогових дозах $\left(1 / 20 L_{50}\right)$ супроводжується розвитком ендоген- ної інтоксикації та порушенням фрункцій печінки, збільшенням вмісту молекул середньої маси і зростанням активності амінотранссрераз (аланінта аспартатамінотранссрераз).

2. Одночасне введення Плюмбуму ацетату, Купруму сульфрату і гліфосату спричиняе підвищення активності аланін- та аспартатамінотрансфераз у щурів усіх вікових періодів, особливо молодих (аланінамінотрансфераза $(15,39 \pm 0,30)$ кмоль ПВК/(г протеїнухгод); аспартатамінотранссрераза - $(11,53 \pm 0,31)$ кмоль ПВК/ (г протеїнухгод)).

3. Введення пептиду як коригувального чинника щурам із токсичним ураженням печінки знижує в сторону норми вміст молекул середньої маси й активність аланін- та аспартатамінотрансфрераз.

Перспективи подальших досліджень. Заплановано вивчити коригувальну дію низькомолекулярних пептидів на показники ліпідного обміну в щурів, уражених Купруму сульсратом, Плюмбуму ацетатом і раундапом.

\section{СПИСОК ЛІТЕРАТУРИ}

1. GC-MS analysis and hepatoprotective activity of the n-hexane extract of Acrocarpus fraxinifolius leavesagainst paracetamol-induced hepatotoxicity in male albino rats / E. A. Abd El-Ghffar, H. A. El-Nashar, O. A. Eldahshan [et al.] // Pharm. Biol. - 2017 - 55 (1). P. 441-449. (http://dx.doi.org/10.1080/13880209.2016.1 246575).

2. Гнатейко О. 3. Екогенетичні аспекти патології людини, спричиненої впливом шкідливих фракторів зовнішнього середовища / О. З. Гнатейко, Н. С. Лук'яненко // Здоровье ребенка. -2007. - № 6 (9). - С. 82-87.

3. Трахтенберг И. М. Книга о ядах и отравлениях / И. М. Трахтенберг. - К. : Наукова думка, 2000. - 366 с.

4. Харів М. І. Динаміка активності амінотранссрераз сироватки крові щурів за оксидаційного стресу та дії ліпосомального препарату / М. І. Харів // Вісн. Дніпропетр. ун-ту. Серія "Біологія і медицина". 2016. - № 7 (1). - С. 3-7.

5. Радченко О. М. Синдром ендогенної інтоксикації в клініці внутрішніх хвороб (огляд літератури та власні спостереження) / О. М. Радченко, М. О. Кондратюк // Мед. гідрологія та реабілітація. - 2009. 7, № 3. - C. 25-32.

6. Ishchuk T. V. Changes in blood protein composition under experimental chemical burns of esophageal development in rats / T. V. Ishchuk // Biomedical Research and Therapy. - 2015. - 2, No. 4. - P. 181-189. (http:// doi.org/10.7603/s40730-015-0009-x).

7. Андрейчин С. М. Сучасні уявлення про метаболічну ендогенну інтоксикацію / С. М. Андрейчин, Т. О. Голомша // Інфекційні хвороби. - 2012. - № 1. C. 84-87.
8. Фейса С. В. Ендогенна інтоксикація та можливості ії̈ медикаментозної корекції у пацієнтів з хронічними дисрузними захворюваннями печінки / С. В. Фейca, І. В. Чопей // Наук. вісн. Ужгород. ун-ту. Серія "Медицина". - 2011. - Вип. 40. - С. 85-89.

9. Сучасні підходи щодо профрілактики інтоксикацій важкими металлами / І. М. Трахтенберг, Н. М. Дмитруха, К. П. Козлов [та ін.] // Таврический мед.-биол. вестн. - 2012. - 15, № 1 (57). - С. 253-257.

10. Свинцева небезпека в Україні: сучасні реалії, проблеми та шляхи вирішення / І. М. Трахтенберг, С. П. Луговський, Н. М. Дмитруха [та ін.] // Наук. журн. МО3 України. - 2013. - № 3 (4).- С. 50-60.

11. Вплив тривалого вживання малих доз хлористого кадмію на екскреторну діяльність нирок у білих щурів за умов водного навантаження / К. М. Чала, А. А. Ходоровська, Г. М. Чернікова, І. С. Попова // Буковин. мед. вісн. -2018. - 22, № 1. C. 149-154.

12. Saxena G. Changes in brain biogenic amines and heme-biosynthesis and their response to combined administration of succimer and Centella asiatica in lead poisoned rats / G. Saxena // J. Pharm. Pharmacol. 2006. - 58. - P. 547-559.

13. Mishra D. Quercetin administration during chelation therapy protects arsenic induced oxidative stress in mouse./ D. Mishra // Biol. Trace Elem. Res. 2008. - 122 - P. 137-147.

14. Blanusa M. Chelators as antidotes of metal toxicity: therapeutic and experimental aspects / M. Blanusa, V. M. Varnai, M. Piasek [et al.] // Current Medicinal Chemistry. - 2005. - 12, No. 23. - P. 2771-2794. 
15.Pachauri P. Combinational chelation therapy abrogates lead induced neurodegeneration in rats / P. Pachauri, G. Saxena, A. Mehta [et al.] // Toxicol. Appl. Pharmacol. - 2009. - No. 240. - P. 255-265.

16. Махинько В. И. Константы роста и фуункциональные периоды развития в постнатальной жизни белых крыс / В. И. Махинько, В. Н. Никитин // Молекулярные и фризиологические механизмы возрастного развития. - К. : Наукова думка, 1975. - С. 308-326.

17. Про захист тварин від жорстокого поводження : Закон України від 21.02.2006 р. № 3447-IV.

18. Науково-практичні рекомендації з утримання лабораторних тварин та роботи з ними / Ю. М. Ко-

\section{REFERENCES}

1. Abd El-Ghffar, E.A. (2017). GC-MS analysis and hepatoprotective activity of the n-hexane extract of Acrocarpus fraxinifolius leavesagainst paracetamolinduced hepatotoxicity in male albino rats. Pharmaceutical Biology, 55, 441-449. Retrieved from: http://dx.doi.org/1 0.1080/13880209.2016.1246575.

2. Hnateiko, O.Z. (2007). Ecogenetic aspects of human pathology caused by the influence of harmful environmental factors. Child's Health, 6 (9), 82-87 [in Ukrainian].

3. Trakhtenberh, Y.M. (2000). Book about poisons and poisonings. Kyiv: Naukova dumka [in Russian].

4. Khariv, M.I. (2016). Dynamics of indices of aminotransferase activity in the blood serum of rats under conditions of oxidative stress and effect of liposomal medicinal product. Dnipropetrovsk University Herald. Biology, 7 (1), 3-7 [in Ukrainian].

5. Radchenko, O.M. (2009). Endogenous intoxication syndrome in the clinic of internal medicine (literature review and own observations). Medical Hydrology and Rehabilitation, 7 (3), 25-32 [in Ukrainian].

6. Ishchuk, T.V. (2015). Changes in blood protein composition under experimental chemical burns of esophageal development in rats. Biomedical Research and Therapy, 2, 181-189. Retrieved from: (http://doi. org/10.7603/s40730-015-0009-x).

7. Andreichyn, S.M. (2012). Modern presentations aboutmetabolic endogenousintoxication. Infectious Diseases, 1, 84-87 [in Ukrainian].

8. Feisa, S.V. (2011). Endogenous intoxication and possibilities of pharmacological therapy in patients with chronic diffuse liver diseases. Scientific Bulletin of Uzhhorod University. Series "Medicine", 40, 85-89 [in Ukrainian].

9. Trakhtenberh, I.M., Dmytrukha, N.M., Kozlov, K.P., \& Krasnokutska, L.M. (2012). Taurian Medical-Biological Herald, 1 (57), 253-257 [in Ukrainian].

10. Trakhtenberh, I.M., Luhovskyi, S.P., Dmytrukha, N.M., Lubyanova, I.P., Talakin Y.M., \& Kharchenko, T.D. (2013). Lead danger in Ukraine: current realities, problems and solutions. Ministry of Health of Ukraine Scientific Journal, 3 (4), 50-56 [in Ukrainian]. жем'якін, О. С. Хромов, М. А. Філоненко, Г. А. Сайфетдінова. - К. : Авіцена, 2002. - 156 с.

19. European convention for the protection of vertebrate animals used for experimental and other scientific purposes. - Council of Europe. Strasbourg, 1986. No. 123. -52 p.

20. Bernard Rosner. Fundamentals of Biostatistics. Boston, USA. - 2010. - 859 p.

21. Лихацький П. Г. Динаміка змін маркерів біоенергетичних процесів та цитолізу у щурів після ураження нітритом натрію на тлі тютюнової інтоксикації / П. Г. Лихацький, Л. С. Фіра, Я. І. Гонський // Вісн. проблем біології і медицини. - 2017. - № 2 (136). С. 147-152.

11. Chala, K.M., Khodorovska, A.A., Chernikova, H.M., \& Popova, I.S. (2018). Influence of long-term intake of low doses of cadmium chloride on the excretory activity of kidneys in white rats under a water loading. Bukovinian Medical Herald, 22 (1), 149-154 [in Ukrainian].

12. Saxena, G. (2006). Changes in brain biogenic amines and heme-biosynthesis and their response to combined administration of succimer and Centella asiatica in lead poisoned rats. Journal of Pharmacy and Pharmacology, 58, 547-559.

13. Mishra, D. (2008). Quercetin administration during chelation therapy protects arsenic induced oxidative stress in mouse. Biological Trace Element Research, 122, 137-147.

14. Blanusa, M. (2005). Chelators as antidotes of metal toxicity: therapeutic and experimental aspects. Current Medicinal Chemistry, 12, 2771-2794.

15. Pachauri, P., Saxena, G., \& Mehta, A. (2009). Combinational chelation therapy abrogates lead induced neurodegeneration in rats. Toxicology and Applied Pharmacology, 240, 255-265.

16. Makhinko, V.I., \& Nikitin, V.N. (1975). Growth constants and functional development periods in the postnatal life of white rats. Molecular and physiological mechanisms of age development. Kyiv [in Russian].

17. The Law of Ukraine "On the Protection of animals from ill-treatment" of February 21, 2006, No. 3447 [in Ukrainian].

18. Kozhemiakin, Yu.M., Khromova, O.S., \& Filonenko, M.A. (2002). Scientific and practical recommendations for the maintenance of laboratory animals and work with them. Kyiv: Avitsena [in Ukrainian]

19. (1986). European convention for the protection of vertebrate animals used for experimental and other scientific purposes Council of Europe. Strasbourg.

20. Rosner, B. (2010). Fundamentals of Biostatistics. Boston, USA.

21. Lykhatskyi, P.H., Fira, L.S., \& Honskyi, Ya.I. (2017). Dynamics of changes of markers of bioenergy processes and cytolysis in rats after the disturbance of sodium nitrite on the background of tobacco intoxication. Herald of Biology and Medicine Problems, 2 (136), 147152 [in Ukrainian]. 


\title{
AGE FEATURES OF CHANGES OF INDICATORS IN ENDOGENOUS INTOXICATION AND MEMBRANE STATE UNDER HEAVY METALS AND GLYPHOSATE ACTION
}

\begin{abstract}
Summary
Introduction. Heavy metals are group of xenobiotic which have the greatest stability in the environment and polytropic toxins for humanity. Heavy metals are blocking functional-active groups of proteins and structural enzymes, namely blocking sulfhydryl (thiol) group (SH). Under the action of heavy metals, most proteins lose their physicochemical and biological properties, which leads to disruption of protein and other metabolism.

The aim of the study - to investigate the effect of lead acetate, copper sulfate and glyphosate (roundup) and the cysteyl-histidyl-tyrosyl-histidyl-isoleucine on changes in endogenous intoxication and membrane status in rats of different ages.

Research Methods. The experiment was carried out on lab nonlinear white rats - males of three age periods: puberty, mature and old aging animals. The rats were administered intragastrically for 30 days aqueous solutions of lead acetate, copper sulfate, glyphosate (in herbicide Roundup). For correction on day 21, 6 hours after toxicant administration, the peptide (cysteyl-histidyl-tyrosyl-histidyl-isoleucine) was administered for 10 days. The activity of alanine aminotransferase (ALT, CF 2.6.1.2), aspartate aminotransferase (AST, CF 2.6.1.1) and the content of medium mass molecules (MMM) were determined in the serum of affected and corrected rats.

Results and Discussion. As our studies showed, the administration of lead acetate, copper sulfate and glyphosate led to changes in protein metabolism in animals of different ages. These toxicants increased the content of MMM and the activity of aminotransferases in the blood plasma of affected rats. Under the action of lead acetate, copper sulfate and glyphosate and their combination, an increase in the activity of aminotransferases in the serum of animals was observed. The most pronounced increase in the activity of these enzymes was observed in 3-monthold rats. Thus, the activity of the enzyme ALT was higher by $164 \%$ under the affect of copper sulfate, $184 \%$ - lead acetate, $276 \%$ - glyphosate, $428 \%$ - in their combined damage compared to control (intact animals). The activity of the enzyme AST varied in the same way as the activity of ALT. It increased by 2.6; 2.7; 2.1 times in the serum of 3-, 6- and 24-month-old animals with combined lesions $(p<0.05)$, respectively.

Conclusions. Liver function is suppressed by 30 days of toxic effects of lead acetate, copper sulfate and glyphosate (roundup) at a dose of 1/20 LD ${ }_{50}$. Increased serum MMM and aminotransferase (ALT, AST) activity indicated toxic hepatitis syndrome. Administration of the peptide (cysteyl-histidyl-tyrosyl-histidyl-isoleucine) as a corrective factor to rats of different ages with toxic liver damage reduces the enzymatic activity of aminotransferases and the content of medium mass molecules.
\end{abstract}

KEY WORDS: lead acetate; copper sulfate; glyphosate; middle mass molecules; aminotransferase.

Отримано 10.11.21

Адреса для листування: Є. Б. Дмухальська, Тернопільський національний медичний університет імені І. Я. Горбачевського моз України, майдан Волі, 1, Тернопіль, 46001, Україна, e-mail: dmukhalska@tdmu.edu.ua. 